\title{
Initial Substrate Moisture Content Affects Chemical Properties of Bagged Substrates Containing Controlled Release Fertilizer at Two Different Temperatures
}

\author{
Ka Yeon Jeong ${ }^{1}$ \\ Department of Horticulture and Crop Science, The Ohio State University, \\ 2021 Coffey Road, Columbus, OH 43210
}

\author{
James E. Altland ${ }^{2,3}$ \\ USDA-ARS, Application Technology Research Unit, Ohio Agricultural \\ Research and Development Center, 1680 Madison Avenue, Wooster, OH \\ 44691
}

Additional index words. electrical conductivity, microbial activity, nitrate, nitrogen immobilization, nutrient release, $\mathrm{pH}$, phosphate, potassium

\begin{abstract}
Bagged potting mixes can be stored for weeks or months before being used by consumers. Some bagged potting mixes are amended with controlled release fertilizers (CRFs). The objective of this research was to determine how initial substrate moisture content and storage temperature affect the chemical properties of bagged potting mix with CRF incorporated and stored for up to 180 days. The base substrate composed of 60 sphagnum peat: 30 bark : 10 perlite (by vol.) amended with $5.5 \mathrm{~g} \cdot \mathrm{L}^{-1}$ dolomitic limestone and $0.5 \mathrm{~g} \cdot \mathrm{L}^{-1}$ granular wetting agent. This base substrate was either not amended with additional fertilizer (control) or amended with $0.59 \mathrm{~kg} \cdot \mathrm{m}^{-3} \mathrm{~N}$ of a CRF (Osmocote $18 \mathrm{~N}$ 1.3P-5K) that was either ground (CRF-G) or whole prills (CRF-P). Substrates had initial moisture contents (IMCs) of $25 \%, 45 \%$, or $65 \%$ and were stored at temperatures of either 20 or $40{ }^{\circ} \mathrm{C}$. IMC and fertilizer type affected $\mathrm{pH}$, electrical conductivity (EC), and nutrient release. Substrate $\mathrm{pH}$ increased with increasing IMC due to greater lime reactivity. About $25 \%$ of $N$ from CRF-G treatments was immobilized between 2 and 14 days of storage. Low moisture content of bags, due to low IMC or storage at $40^{\circ} \mathrm{C}$, reduced the rate of $\mathrm{N}$ release from CRF-P treatments. Substrate $P$ was rapidly immobilized by microbial communities.
\end{abstract}

Consumer potting mixes are designed for container gardening, hanging baskets, indoor plants, and raised beds. They are often purchased at mass merchants or garden centers in plastic bags to facilitate transportation and storage by consumers. The primary component of these potting mixes is sphagnum peatmoss. The United States used over 14 million cubic meters of peat for horticultural applications in 2014, while worldwide usage was 100 million cubic meters (Apodaca, 2016). Specific uses of imported peat within the horticulture industry are not known. However, Slivka et al. (1992) estimate 4.5-6.0 million cubic meters of bagged potting soil are purchased by homeowners and landscapers annually.

Some bagged potting mixes include one or more types of fertilizer to provide plant nutrients. There can be a significant delay,

\footnotetext{
Received for publication 14 June 2017. Accepted for publication 22 Aug. 2017.

${ }^{1}$ Research Assistant.

${ }^{2}$ Research Horticulturist.

${ }^{3}$ Corresponding author. E-mail: james.altland@ ars.usda.gov.
}

weeks or months, from the time the potting mixes are bagged and stored until they are purchased and used by consumers. As such, nutrient release from the fertilizers and changes in the chemical properties of bagged potting mixes in storage have been studied. Carlile (2004) warned that in potting mixes containing CRFs, the slow release of the nutrients over time can lead to serious problems stemming from high nutrient levels and soluble salts at the time of use. It has been suggested by both manufacturers (Hulme, 2011) and researchers (Carlile, 2004; Zaccheo et al., 2013) that media with CRF be used immediately after mixing (within $30 \mathrm{~d}$ ) to avoid problems with soluble salts.

Temperature and moisture content are the primary factors affecting CRF release and microbial activities, such as nitrification and nitrogen $(\mathrm{N})$-immobilization, in bagged potting mixes during storage (Cabrera, 1997; Husby et al., 2003). Zaccheo et al. (2013) measured the chemical properties of two peat-based substrates amended with CRF (product not specified) and stored over a 12-month period at either $21{ }^{\circ} \mathrm{C}$ (which the authors considered proper) or stored for $15 \mathrm{~d}$ at $40{ }^{\circ} \mathrm{C}$ and the remainder of the time at $21{ }^{\circ} \mathrm{C}$ (considered improper). Elevated temperatures for just $15 \mathrm{~d}$ resulted in greater dissolution of lime in the substrate and greater release of ammonium $\left(\mathrm{NH}_{4}{ }^{+}\right)$ through the first $120 \mathrm{~d}$ compared with the substrates stored at constant $21^{\circ} \mathrm{C}$. SelmerOlsen and Gislerod (1986) evaluated the change in $\mathrm{N}$ form in a peat substrate stored at 4 to $35{ }^{\circ} \mathrm{C}$. They observed greater reductions in the amount of recoverable $\mathrm{N}$, as well as greater changes of $\mathrm{N}$ form, in substrates stored at 12 to $35^{\circ} \mathrm{C}$ compared with substrates stored at $4{ }^{\circ} \mathrm{C}$. Dickinson and Carlile (1995) showed that a peat substrate amended with inorganic nutrients (unspecified) at $2 \mathrm{~kg} \cdot \mathrm{m}^{-3}$ stored at $20^{\circ} \mathrm{C}$ resulted in a greater increase in nitrate $\left(\mathrm{NO}_{3}{ }^{-}\right)$and decrease in $\mathrm{NH}_{4}{ }^{+}$over a 12 -month period compared with storage at $10{ }^{\circ} \mathrm{C}$. This was attributed to an increased microbial activity at the higher temperature.

Moisture content during storage can also affect substrate quality and nutrient release. Selmer-Olsen and Gislerod (1986) also evaluated substrate quality when stored at $30 \%$ to $75 \%$ moisture content. They observed greater nitrification rates in peat stored at higher moisture contents and speculated that $\mathrm{N}$ loss in drier substrates $(30 \%$ moisture content) was due to $\mathrm{N}$-immobilization and not nitrification. Likewise, Saadi et al. (2010) reported that microbial activity of composts using organic nutrient sources stored at $55 \%$ to $65 \%$ moisture content was greater than those stored at $15 \%$ to $35 \%$ moisture content, which resulted in higher $\mathrm{NO}_{3}{ }^{-}$concentration due to increased nitrification under wet conditions.

One of the most important implications of nutrient release from CRFs in bagged substrates is how it affects shelf life. While research has shown general trends in how moisture content and temperature affect $\mathrm{pH}, \mathrm{EC}$, and nutrient dynamics in stored substrates, they do not provide specific information on 1) how quickly nutrients are released from a CRF, 2) how much nutrients are immobilized, and 3) how $\mathrm{N}$ forms are transformed between inorganic forms $\left(\mathrm{NH}_{4}{ }^{+}\right.$and $\left.\mathrm{NO}_{3}{ }^{-}\right)$. The objective of this research was to determine over time how initial substrate moisture content and storage temperature affect the chemical properties and available nutrients derived from a CRF incorporated into a bagged peat-based substrate and stored for up to $180 \mathrm{~d}$.

\section{Materials and Methods}

The base substrate was 60 sphagnum peat: 30 aged pine bark fines: 10 perlite (by vol.) amended with $5.5 \mathrm{~g} \cdot \mathrm{L}^{-1}$ dolomitic limestone (ECOPHRST; National Lime and Stone Co., Findlay, $\mathrm{OH}$ ) and $0.5 \mathrm{~g} \cdot \mathrm{L}^{-1}$ granular wetting agent (AquaGro 2000G; Aquatrols, Paulsboro, NJ). The treatment design was a $3 \times 3$ factorial arrangement with three moisture levels and three fertilizer treatments. Water was added to the 
base substrate to attain IMC of $25 \%, 45 \%$, or $65 \%$, calculated as the mass of water per mass of wet substrate.

The fertilizer treatments included the base substrate described previously with lime and wetting agent only as a nonfertilized control, or a CRF (Osmocote 18N2.6P-9.96K, 8-9 months; The Scotts Co., Marysville, $\mathrm{OH}$ ) in its original CRF-P or CRF-G before amendment. The prills for the CRF-G treatment were ground with a coffee grinder to physically break the coating layer and to induce immediate and complete nutrient release at the time of potting. Both CRF treatments were incorporated at $0.59 \mathrm{~kg} \cdot \mathrm{m}^{-3} \mathrm{~N}$. The $\mathrm{CRF}-\mathrm{G}$ treatment served as a positive control to determine the maximum amount of nutrients that would be available without interference from the CRF coating.

After fertilizer treatments were mixed into the base substrate, $0.4 \mathrm{~L}$ of each was placed in $10 \times 15 \mathrm{~cm}, 2$ mil sealable plastic bags (Royal Bag, Brooklyn, NY). Each bag was perforated with four holes to simulate the perforation of commercial bagged potting mixes. The bags were placed in a growth chamber (VWR Signature Diurnal Growth Chamber, Model 2015; VWR International, Radnor, PA) set to 20 or $40{ }^{\circ} \mathrm{C}$. Because the growth chambers could not be replicated for practical reasons, differences in nutrient release from the substrates between the two storage temperatures will not be compared statistically, but will be discussed. There were four bagged replicates of each fertilizer, temperature, and moisture level combination for each of five harvest dates at 2, 14, 30, 90, and $180 \mathrm{~d}$ after mixing.

Two days after the substrate treatments were mixed, but before they were placed in growth chambers for storage, four replicate bags of each fertilizer and moisture treatment combination were analyzed for water extractable nutrients using a modified saturated media extraction procedure. Substrates were transferred each to a $1 \mathrm{~L}$ sealable plastic bag, and $350 \mathrm{~mL}$ of reverse osmosis water was added. The substrate slurry was allowed to come to equilibrium for $30 \mathrm{~min}$. Afterward, a small hole was cut into the corner of the bag and placed immediately over PVC Buchner funnels $(13.1 \mathrm{~cm}$ i.d., $6.6 \mathrm{~cm}$ tall; Thermo Fisher Scientific, Waltham, MA) fitted with a fiberglass filter paper (G6; Thermo Fisher Scientific). The Buchner funnels were attached to an erlenmeyer flask and placed under vacuum (maximum of $101 \mathrm{kPa}$ ) using an electric pump (Duoseal Vacuum Pump 1376; Welch Vacuum Technology, Inc., Skokie, IL) to facilitate extraction of the water from the substrate and through the filter paper. Filtrates were immediately placed in a refrigerator and stored at $2{ }^{\circ} \mathrm{C}$ until the time of analysis.

At analysis, $\mathrm{pH}$ was determined with a $\mathrm{pH} /$ ion analyzer (MA 235; Metler Toledo, Columbus, $\mathrm{OH}$ ) and EC with a conductivity meter (Fisher 06-662-61; Thermo Fisher
Scientific). Samples were subsequently filtered through GF/F binder-free borosilicate glass fiber filter paper (Whatman Ltd., Kent, UK) to remove particles greater than $0.7 \mu \mathrm{m}$. The filtrate was poured into 5-mL autosampler vials, capped, and analyzed using ion chromatography (ICS 1600 Ion Chromatography System; Dionex, Bannockburn, IL) for concentrations of $\mathrm{NO}_{3}^{-}, \mathrm{NH}_{4}^{+}$, and phosphate $\left(\mathrm{PO}_{4}{ }^{2-}\right)$. Three additional bags for each moisture level treatment were analyzed for moisture content by weighing the contents of the bag, drying in an oven at $110{ }^{\circ} \mathrm{C}$ for $3 \mathrm{~d}$, and weighing again. Nutrient concentrations determined by ion chromatography were converted to mass ( $\mathrm{mg}$ ) of each nutrient using the volume of water applied for the extraction process $(350 \mathrm{~mL})$ and the volume of water measured as moisture content.

Four replicates of each treatment combination were subsequently removed from each chamber at $14,30,90$, and $180 \mathrm{~d}$ after the substrates were mixed and subjected to the same extraction and nutrient analysis described previously. Likewise, three bags for each temperature and moisture level treatment combination were measured for percent moisture content.

Data were subjected to analysis of variance and correlation analysis, when appropriate, using statistical software (SAS v9.3; SAS Institute, Cary, NC). Data were plotted as means with error bars representing the $95 \%$ confidence interval about the mean, using graphing software (SigmaPlot 12.5; SYSTAT Software, Inc., Chicago, IL).

\section{Results and Discussion}

Moisture content of the bagged substrates changed over time (Fig. 1). There were significant interactions between IMC and day for bags stored in both 20 and $40{ }^{\circ} \mathrm{C}$ chambers $(P<0.0001$, data not shown $)$. Although not compared statistically, bags stored at $40{ }^{\circ} \mathrm{C}$ seemed to have lost more moisture over the $180 \mathrm{~d}$ experiment than those stored at $20{ }^{\circ} \mathrm{C}$. Over the duration of the experiment, moisture in bags with $25 \%$, $45 \%$, and $65 \%$ IMC stored at $20{ }^{\circ} \mathrm{C}$ were reduced by $17 \%, 28 \%$, and $13 \%$, respectively, whereas those stored at $40{ }^{\circ} \mathrm{C}$ were reduced by $21 \%, 41 \%$, and $60 \%$, respectively. The forced-air feature of the growth chambers, along with the relatively small bag volume (compared with commercial sizes) resulted in accelerated moisture loss. The original intent of the holes was to prevent anoxic and anaerobic conditions in the media. Vent holes are also routinely used in commercial bagged potting media, although commercial bags are stacked and wrapped collectively on a pallet such that there is very little moisture loss over time (personal communication and several commercial sources).

Substrate $\mathrm{pH}$ was affected by fertilizer, IMC, and day for samples stored at both 20 and $40{ }^{\circ} \mathrm{C}$ (Table 1). Substrate $\mathrm{pH}$ increased with increasing IMC in both storage temperatures (Fig. 2). Dissolution of dolomitic limestone added to potting mixes can cause a gradual increase in media $\mathrm{pH}$ over time (Carlile, 2004). The calcium and magnesium carbonate $\left[\mathrm{CaMg}\left(\mathrm{CO}_{3}\right)_{2}\right]$ in dolomitic lime dissociates in water to form exchangeable $\mathrm{Ca}^{2+}$ and $\mathrm{Mg}^{2+}$, as well as carbon dioxide and additional water molecules (Lindsay, 1979). This reaction consumes two hydrogen ions $\left(\mathrm{H}^{+}\right)$and thus causes $\mathrm{pH}$ to increase. While water is necessary for the reaction to occur, there is no literature addressing the impact of moisture level in soils or soilless substrates on lime reactivity. However, Altland and Jeong (2016) described how solubility of dolomitic lime and other weak bases is limited by $\mathrm{pH}$, thus lime dissociation should increase with increasing water availability. Fertilizer treatment also affected substrate $\mathrm{pH}$ (Table 1 ). The two fertilized substrates (CRF-P and CRF-G) had similar or lower $\mathrm{pH}$ than the nonfertilized control. The CRF used in this experiment contained equal parts $\mathrm{NO}_{3}{ }^{-}$and $\mathrm{NH}_{4}{ }^{+}$forms of N. $\mathrm{NH}_{4}{ }^{+}$is readily oxidized to $\mathrm{NO}_{3}{ }^{-}$and in the process evolves $\mathrm{H}^{+}$ions
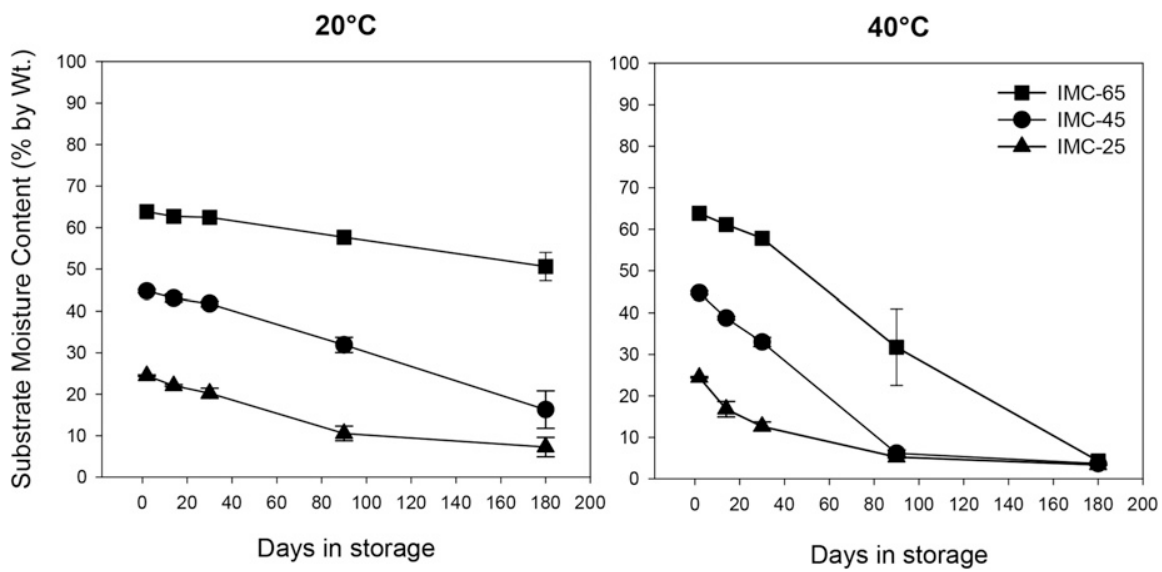

Fig. 1. Mean moisture content (\%, by weight) of bagged substrates composed of 60 sphagnum peat: 30 bark : 10 perlite by volume. Error bars represent $95 \%$ confidence intervals about the mean. Substrates had initial moisture contents (IMC) of $65 \%, 45 \%$, or $25 \%$, and the bagged substrates were stored in a growth chamber at temperatures of either $20^{\circ} \mathrm{C}$ (left) or $40{ }^{\circ} \mathrm{C}$ (right) for $180 \mathrm{~d}$. 
Table 1. Probability values ( $P$ value) for main effects and interactions of fertilizer type, initial moisture content, and day of collection on the $\mathrm{pH}$, electrical conductivity $(\mathrm{EC})$, inorganic nitrogen $(\mathrm{N})$, and phosphorus $(\mathrm{P})$ recovered in bagged substrates stored at 20 or $40^{\circ} \mathrm{C}$.

\begin{tabular}{llcccc}
\hline Temp $\left({ }^{\circ} \mathrm{C}\right)$ & & $\mathrm{pH}$ & $\mathrm{EC}$ & $\mathrm{N}$ & $\mathrm{P}$ \\
\hline 20 & $\mathrm{~F}$ & 0.0001 & 0.0001 & 0.0001 & 0.0001 \\
& $\mathrm{M}$ & 0.0001 & 0.1517 & 0.0001 & 0.0001 \\
& $\mathrm{~F} * \mathrm{M}$ & 0.1034 & 0.0001 & 0.0001 & 0.0001 \\
& $\mathrm{D}$ & 0.0052 & 0.0001 & 0.0001 & 0.0001 \\
& $\mathrm{D} * \mathrm{~F}$ & 0.0004 & 0.0001 & 0.0001 & 0.0001 \\
& $\mathrm{D}{ }^{* \mathrm{M}}$ & 0.0001 & 0.0001 & 0.0001 & 0.0001 \\
& $\mathrm{D} \mathrm{F}^{*} \mathrm{M}$ & 0.1031 & 0.0001 & 0.0001 & 0.0001 \\
& $\mathrm{~F}$ & 0.0001 & 0.0001 & 0.0001 & 0.0001 \\
$\mathrm{M}$ & 0.0001 & 0.0001 & 0.0001 & 0.0001 \\
& $\mathrm{M}$ & 0.0295 & 0.0001 & 0.0001 & 0.0001 \\
& $\mathrm{~F} \mathrm{M}$ & 0.0001 & 0.0001 & 0.0001 & 0.1409 \\
& $\mathrm{D}$ & 0.0001 & 0.0001 & 0.0001 & 0.0010 \\
& $\mathrm{D} * \mathrm{~F}$ & 0.0001 & 0.0001 & 0.0037 & 0.3019 \\
& $\mathrm{D} * \mathrm{M}$ & 0.0032 & 0.0001 & 0.0001 & 0.4361 \\
\hline
\end{tabular}

$\mathrm{D}=$ day; $\mathrm{F}=$ fertilizer; $\mathrm{M}=$ moisture.

$20^{\circ} \mathrm{C}$
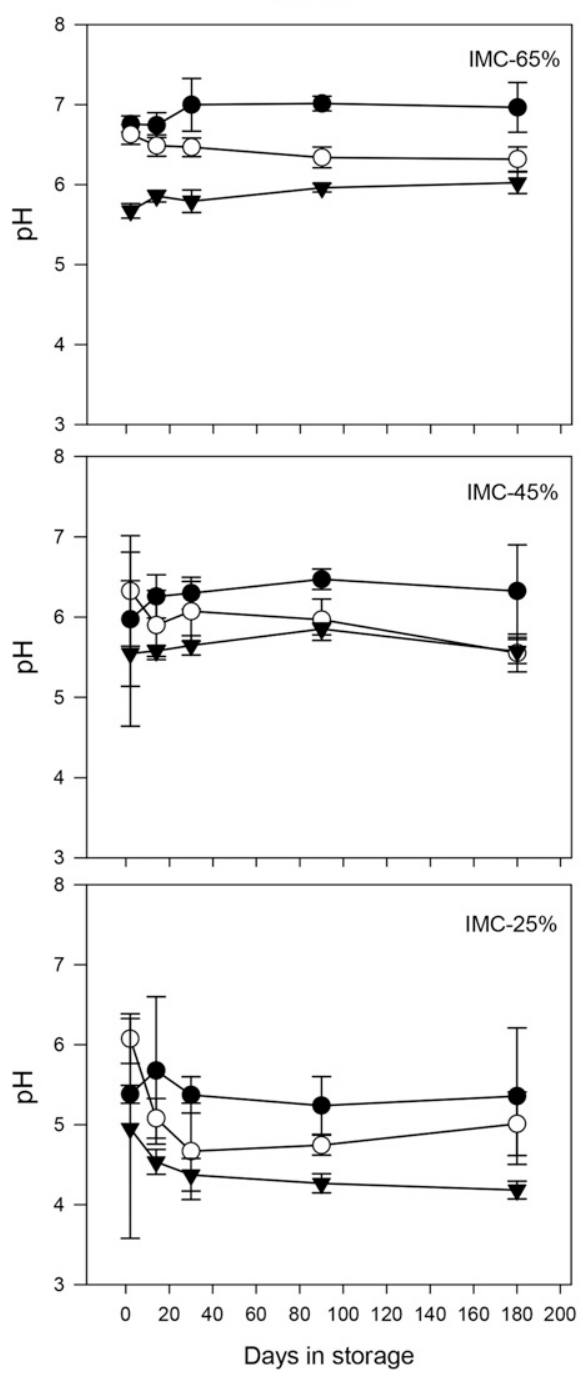

$40{ }^{\circ} \mathrm{C}$
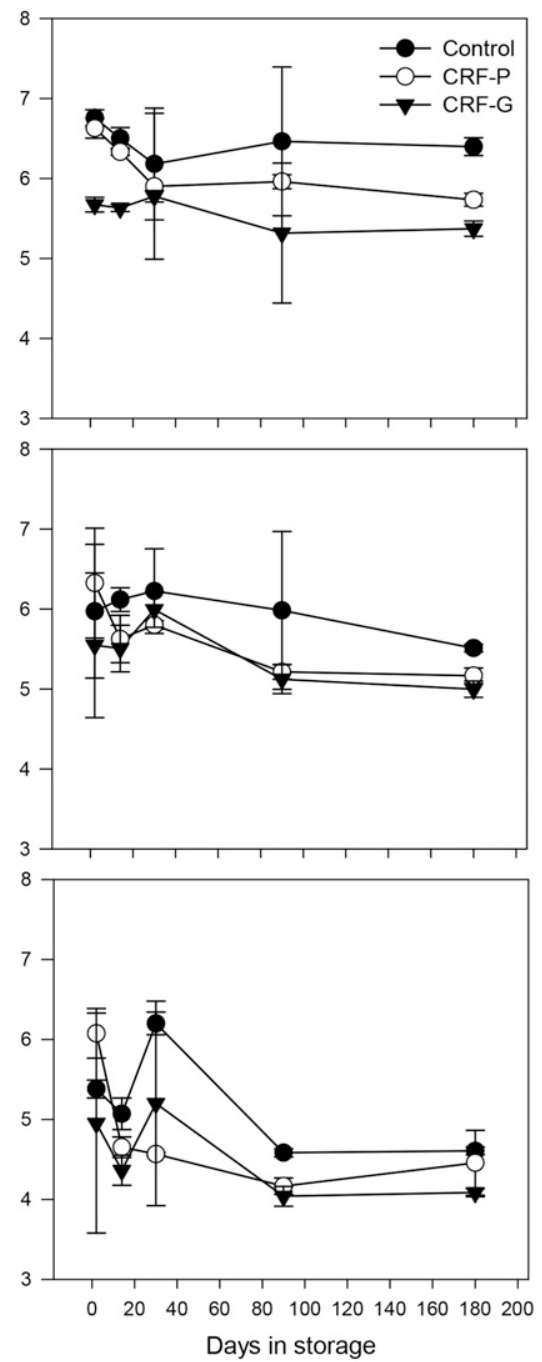

Fig. 2. Substrate $\mathrm{pH}$ of bagged substrates composed of 60 sphagnum peat: 30 bark : 10 perlite by volume. Substrates were amended with $5.5 \mathrm{~g} \cdot \mathrm{L}^{-1}$ dolomitic limestone and had initial moisture content (IMC) of $65 \%$ (top), $45 \%$ (middle), or $25 \%$ (lower), and stored in a growth chamber set to $20^{\circ} \mathrm{C}$ (left) or $40{ }^{\circ} \mathrm{C}$ (right) during 180 -d storage period. Substrates were also either not amended with fertilizer (control), or amended with 0.59 $\mathrm{kg} \cdot \mathrm{m}^{-3} \mathrm{~N}$ of a controlled release fertilizer (CRF) (Osmocote $\left.18 \mathrm{~N}-1.3 \mathrm{P}-5 \mathrm{~K}\right)$ that was either ground (CRF-G) or whole prills (CRF-P). Error bars represent the $95 \%$ confidence interval about the mean.

that lower pH. Zaccheo et al. (2013) also reported a strong acidification effect from two different CRF formulations that both had $50 \%$ of its $\mathrm{N}$ as $\mathrm{NH}_{4}{ }^{+}$. They attributed this substrate acidification to oxidation of $\mathrm{NH}_{4}{ }^{+}$from the CRF. The $\mathrm{pH}$ of the CRF-G substrate was similar or lower than the CRF-P substrate throughout the experiment when stored at 20 or $40{ }^{\circ} \mathrm{C}$. The total mass of $\mathrm{NH}_{4}^{+}$would have been immediately available for oxidation in the CRF-G treatment, compared with the relatively slow and incomplete release of $\mathrm{NH}_{4}{ }^{+}$from the CRF-P treatment. While not compared statistically, there appeared to be little or no difference in $\mathrm{pH}$ response between the 20 and $40{ }^{\circ} \mathrm{C}$ chambers.

Moisture and fertilizer treatment affected EC in both 20 and $40{ }^{\circ} \mathrm{C}$ chambers either as a main effect or interaction with other factors (Table 1). Nonfertilized substrates had relatively low and stable EC over time in each of the six temperature and IMC treatment combinations (Fig. 3). Likewise, substrates with CRF-G had relatively high $\left(>3 \mathrm{mS} \cdot \mathrm{cm}^{-1}\right)$ and stable EC over time in each of the temperature and IMC treatments. Substrates with CRF-P, however, varied with IMC. At $25 \%$ IMC, EC in CRF-P substrates stayed relatively low $\left(\leq 1 \mathrm{mS} \cdot \mathrm{cm}^{-1}\right)$ throughout the experiment when stored at 20 or $40{ }^{\circ} \mathrm{C}$. The low moisture levels in these substrates likely limited nutrient diffusion through the CRF coating (Fig. 1). At $45 \%$ IMC, EC of the CRF-P substrate increased over time in the $20{ }^{\circ} \mathrm{C}$ chamber, but plateaued after $90 \mathrm{~d}$ in the $40{ }^{\circ} \mathrm{C}$ chamber. This again was likely due to the extremely low moisture contents of the substrates in the $40{ }^{\circ} \mathrm{C}$ chamber, which dropped to below $10 \%$ moisture, while those in $20^{\circ} \mathrm{C}$ were at $31 \%$ moisture. A similar pattern occurred in substrates with $65 \%$ IMC, in that EC increased steadily over time in substrates in $20{ }^{\circ} \mathrm{C}$ storage but plateaued after $90 \mathrm{~d}$ when stored at $40{ }^{\circ} \mathrm{C}$. While not compared statistically, EC increased more rapidly in CRF-P substrates with $65 \%$ IMC stored at $40{ }^{\circ} \mathrm{C}$ compared with $20{ }^{\circ} \mathrm{C}$. For example, EC of CRF-P substrates in the 65\% IMC reached $2.76 \mathrm{mS} \cdot \mathrm{cm}^{-1}$ by $180 \mathrm{~d}$, whereas the same treatment reached an EC of $2.85 \mathrm{mS} \cdot \mathrm{cm}^{-1}$ in just $90 \mathrm{~d}$ at $40{ }^{\circ} \mathrm{C}$. Husby et al. (2003) showed that CRF products with a similar coating to that used in this experiment had increased nutrient release as temperature increased from 20 to $40{ }^{\circ} \mathrm{C}$.

Fertilizer and IMC affected $\% \mathrm{~N}$ recovery over time (Table 1). The nonfertilized substrates did not receive $\mathrm{N}$-fertilizers, so the $\% \mathrm{~N}$ recovery in these treatments represents the contribution of $\mathrm{N}$ from other substrate materials. Very little $\mathrm{N}$ was detected in the nonfertilized substrates, between $1 \%$ and $3 \%$ across all temperature and IMC combinations (Fig. 4).

On day 2, 90.2\% of applied $\mathrm{N}$ was recovered in the CRF-G treatment averaged across the three IMC treatments. The CRF$\mathrm{G}$ treatment served as a positive control to both validate our extraction method and document $\mathrm{N}$-immobilization of the fertilizer. Percent $\mathrm{N}$ recovered would ideally be $100 \%$ in the CRF-G treatment because the coating layer along with the fertilizer content was finely ground before incorporation. 
$20^{\circ} \mathrm{C}$
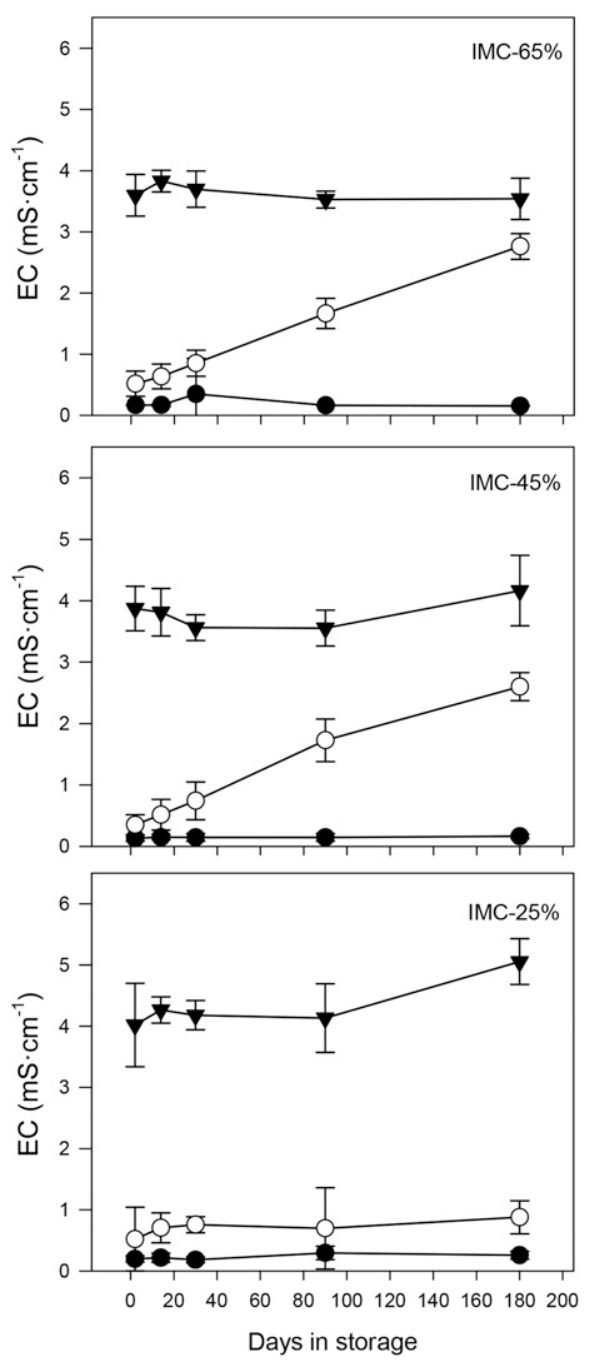

$40{ }^{\circ} \mathrm{C}$
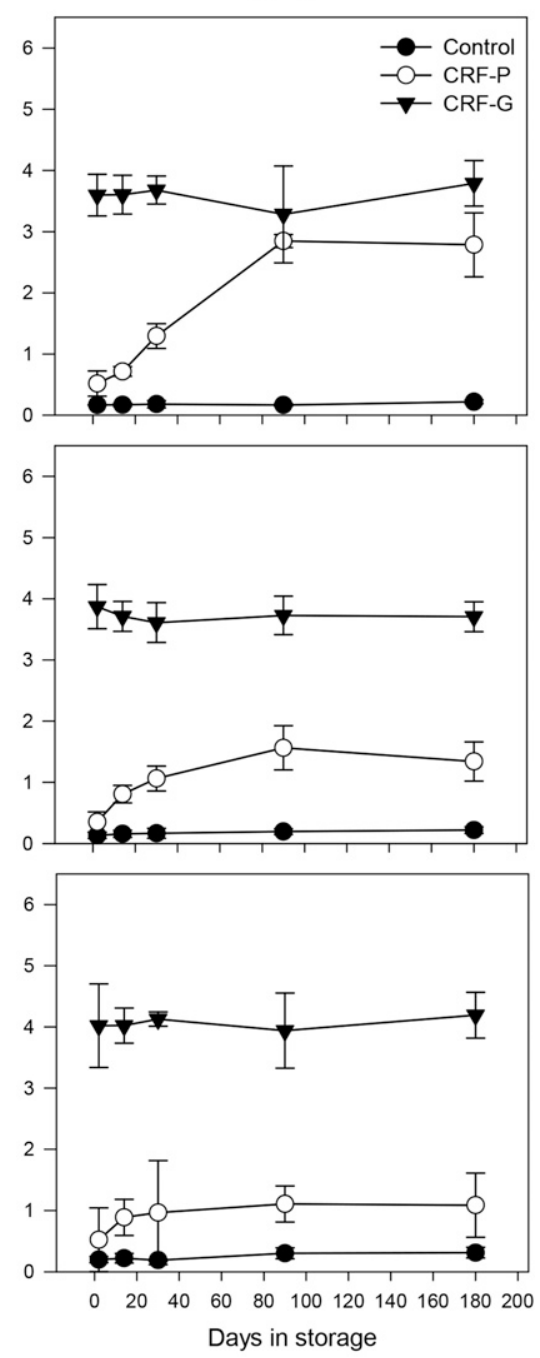

Fig. 3. Substrate EC of bagged substrates composed of 60 sphagnum peat: 30 bark : 10 perlite by volume. Substrates were either not amended with fertilizer (control) or amended with $0.59 \mathrm{~kg} \cdot \mathrm{m}^{-3} \mathrm{~N}$ of a controlled release fertilizer (CRF) (Osmocote $18 \mathrm{~N}-1.3 \mathrm{P}-5 \mathrm{~K})$ that was either ground (CRF-G) or whole prills (CRF-P). Substrates had initial moisture content of $65 \%$ (higher), $45 \%$ (middle), or $25 \%$ (lower) and were stored in a growth chamber at temperatures of either $20{ }^{\circ} \mathrm{C}$ (left) or $40{ }^{\circ} \mathrm{C}$ (right). Error bars represent the $95 \%$ confidence interval about the mean.

Birrenkott et al. (2005) established a threshold of $90 \%$ for $\mathrm{N}$ recovery in CRF leaching systems for accurately documenting CRF release period, acknowledging that as much as $10 \%$ could be unrecoverable in sand or substrate systems. Thus, the $90.2 \%$ recovered on day 2 of this experiment suggests a thorough and accurate recovery rate. By day 14 , only $64.8 \%$ to $69.4 \%$ of $\mathrm{N}$ was recovered from CRF-G in the $20{ }^{\circ} \mathrm{C}$ chambers and $61.6 \%$ to $66.6 \%$ in the $40{ }^{\circ} \mathrm{C}$ chamber. The decrease in $\% \mathrm{~N}$ recovered from day 2 to day 14 in the CRF-G treatment in each of the IMC and temperature combinations were likely the result of microbial $\mathrm{N}$ immobilization. Averaging across all six IMC and temperature combinations, there was a $25 \%$ reduction in detectable $\mathrm{N}$ from the CRF-G treatment by day 14. This represents a reduction of 0.15 $\mathrm{kg} \cdot \mathrm{m}^{-3} \mathrm{~N}$ from the substrate. Our observed values for $\mathrm{N}$ immobilization are similar to previously established rates. Scott (1985) suggested a $0.035 \mathrm{~kg} \cdot \mathrm{m}^{-3}$ reduction in $\mathrm{N}$ because of microbial-induced $\mathrm{N}$ immobilization per $10 \%$ of the substrate composed of pine bark. That equates to $0.105 \mathrm{~kg} \cdot \mathrm{m}^{-3}$ for the substrate used for these experiments, which was composed of $30 \%$ pine bark. Others have suggested $0.14 \mathrm{~kg} \cdot \mathrm{m}^{-3} \mathrm{~N}$ to satisfy microbial populations acting on pine bark substrates (Pokorny, 1979). Birrenkott et al. (2005) reported that total $\mathrm{N}$ recovered from CRF in leachate solutions through a bark-based substrate was significantly lower than through a sand substrate due to $\mathrm{N}$ immobilization. Peat-based media have indigenous microbial populations of $10^{5}$ to $10^{6}$ bacterial colony-forming units (cfu) and $10^{2}$ to $10^{3}$ fungal cfu, whereas bark-based substrates have $10^{6}$ to $10^{7}$ bacterial cfu and $10^{5}$ to $10^{6}$ fungal cfu (Carlile, 2004). Carlile (2004) warns that higher microbial populations in pine bark substrates can lead to greater $\mathrm{N}$ immobilization.
Percent $\mathrm{N}$ recovered from substrates receiving CRF-P was affected by IMC. Recovery of $\mathrm{N}$ from substrates with $25 \%$ IMC was only $16.5 \%$ and $15.9 \%$ after $180 \mathrm{~d}$ in 20 and $40{ }^{\circ} \mathrm{C}$ chambers, respectively, while recovery for those in $45 \%$ IMC was $42.5 \%$ and $20.5 \% \mathrm{~N}$, respectively (Fig. 4). The lower values for $\% \mathrm{~N}$ recovered from $\mathrm{CRF}-\mathrm{P}$ in $45 \%$ IMC and the $40{ }^{\circ} \mathrm{C}$ chamber compared with the $20^{\circ} \mathrm{C}$ chamber are likely due to substrate moisture content. After $90 \mathrm{~d}$, the moisture content of substrates that started with $45 \%$ IMC dropped to $6.1 \%$ moisture in the $40{ }^{\circ} \mathrm{C}$ chamber compared with $31.9 \%$ moisture in the $20^{\circ} \mathrm{C}$ chamber (Fig. 1). Substrates receiving CRF-P with $65 \%$ IMC had similar release patterns in 20 and $40{ }^{\circ} \mathrm{C}$ chambers, with those in the $20^{\circ} \mathrm{C}$ chamber reaching a maximum recovery of $50.0 \%$ and those in the $40{ }^{\circ} \mathrm{C}$ chamber attaining $45.7 \%$ recovery. While nutrient release from a resin or polymer-coated CRF is primarily a function of temperature (Birrenkott et al., 2005; Cabrera, 1997; De Oliveira et al., 2016), others have noted that moisture content in soil or soilless substrates will affect nutrient diffusion out of the CRF prill, and drier soils will reduce the overall rate of nutrient release (Chang-wen et al., 2006; Shaviv et al., 2003). It is not clear what substrate moisture level will slow or halt nutrient release from CRF prills, however, it is likely that the extremely low moisture levels in the substrates stored at $20{ }^{\circ} \mathrm{C}$ with $25 \%$ IMC or any of the samples stored in the $40{ }^{\circ} \mathrm{C}$ chamber reduced nutrient release.

Phosphorus recovery was affected by fertilizer type and IMC in both storage temperatures (Table 1). As expected, little or no $\mathrm{P}$ was recovered from nonfertilized substrates (Fig. 5). Percent $\mathrm{P}$ recovered from CRF-P responded similarly to $\mathrm{N}$ with respect to IMC and temperature. Percent $P$ recovery was low in substrates receiving CRF-P and 25\% IMC, whereas \%P recovered increased from 2 to $180 \mathrm{~d}$ in substrates with $45 \%$ or $65 \%$ IMC. Among CRF-P treatments, $\% \mathrm{P}$ recovery was generally lower than $\% \mathrm{~N}$ recovery. Huett and Gogel (2000) showed that across 17 different polymer-coated CRF products, including five formulations using a coating technology similar to the product in this experiment, the relative release rate was more rapid for $\mathrm{N}$ than $\mathrm{P}$. More rapid release of $\mathrm{N}$ than $\mathrm{P}$ has been attributed to the greater solubility of $\mathrm{N}$ compared with $\mathrm{P}$ compounds (Chang-wen et al., 2006). The percent $P$ recovered from $C R F-G$ substrates was less than $40 \%$ in most cases with $45 \%$ and $65 \%$ IMC. Percent $\mathrm{P}$ recovery in CRFG substrates with 25\% IMC was higher than those with $45 \%$ or $65 \%$ IMC. As discussed previously, higher IMC likely resulted in greater lime dissolution. The higher levels of free $\mathrm{Ca}^{2+}$ might have formed precipitates with $\mathrm{PO}_{4}{ }^{2-}$ from the CRF-G, thus reducing $\% \mathrm{P}$ recovered in the waterextraction process. A more likely reason for low $\% \mathrm{P}$ recovery rates is microbial $\mathrm{P}$ 
$20^{\circ} \mathrm{C}$
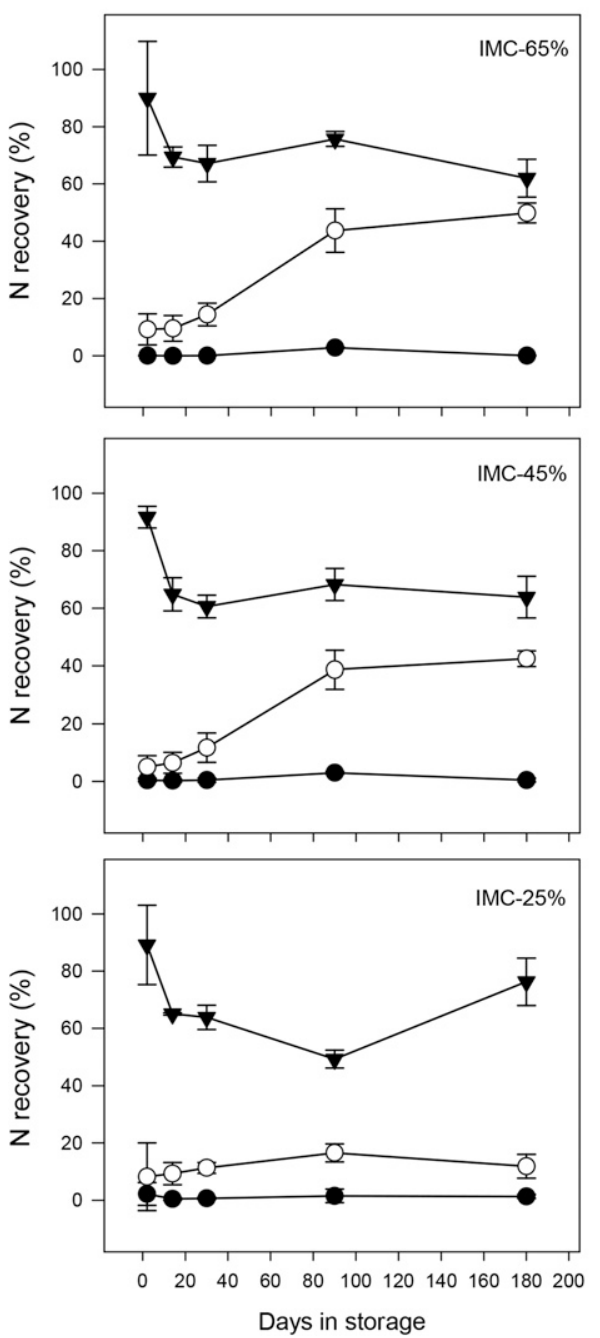

$40{ }^{\circ} \mathrm{C}$
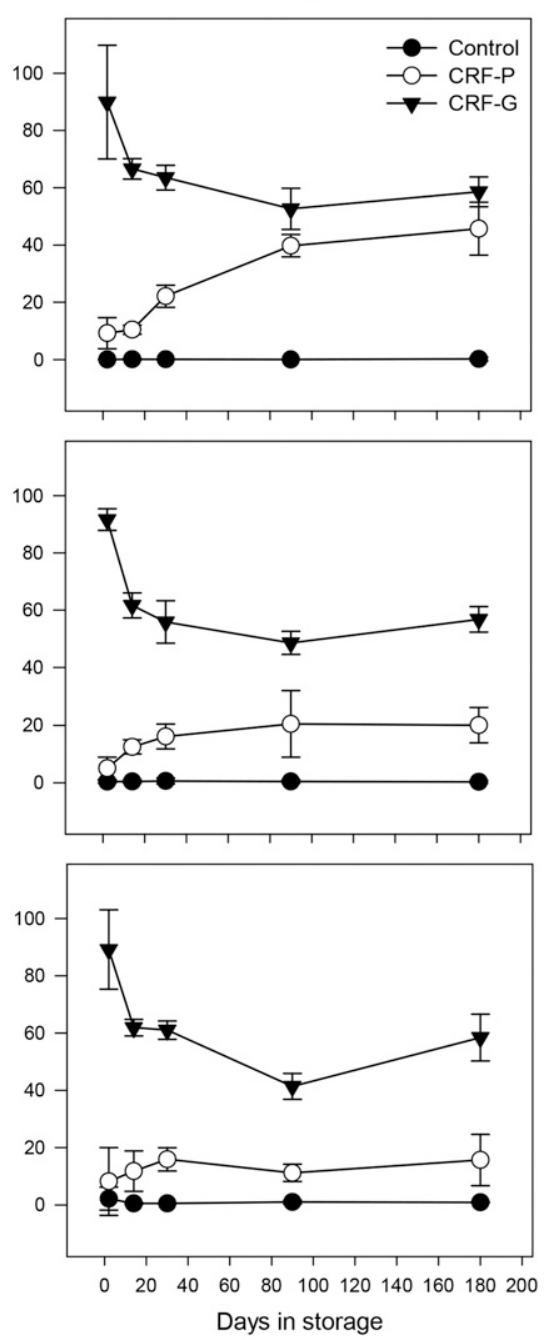

Fig. 4. The recovered water extractable nitrogen $\left(\mathrm{NH}^{4+}+\mathrm{NO}^{3-}\right)$ from a substrate composed of 60 sphagnum peat: 30 bark : 10 perlite by volume. Data are expressed as mean percent of the total mass of $238 \mathrm{mg} \mathrm{N}$ applied via the controlled release fertilizer (CRF). Error bars represent the $95 \%$ confidence interval about the mean. Substrates were either not amended with fertilizer (control) or amended with $0.59 \mathrm{~kg} \cdot \mathrm{m}^{-3} \mathrm{~N}$ of a CRF (Osmocote $18 \mathrm{~N}-1.3 \mathrm{P}-5 \mathrm{~K}$ ) that was either ground (CRF-G) or whole prills (CRF-P). Substrates had initial moisture contents of $65 \%$ (higher), $45 \%$ (middle), or $25 \%$ (lower) and were stored at temperatures of either $20^{\circ} \mathrm{C}$ (left) or $40^{\circ} \mathrm{C}$ (right).

immobilization. Handreck (1996) showed that $40 \%$ to $50 \%$ of extractable $\mathrm{P}$ was reduced in the first $5 \mathrm{~d}$ of a substrate incubation study solely as a function of microbial immobilization. The N:P ratio of all the $\mathrm{N}$ and $\mathrm{P}$ not recovered from the CRF-G substrates ranged from 3.3 to 5.4 with an overall mean of 4.8 (data not presented). The N:P ratio of bacteria is 4.7 on dry weight basis (Brookes et al., 1984; Todar, 2012), which further corroborates the likelihood that unrecovered $\mathrm{P}$ in the CRF-G treatments was due to microbial immobilization.

In summary, IMC and storage temperature affected $\mathrm{pH}, \mathrm{EC}$, and nutrient release. The typical moisture content of bagged potting substrates is $40 \%$ to $60 \%$ (personal communication and several commercial sources). Moisture content of our bags dropped below this typical level, revealing how severely moisture content can affect substrate chemical properties. Substrate $\mathrm{pH}$ increased with increasing IMC due to greater lime reactivity. Because dolomitic lime reactions are chemical and not biological, storage temperature seemed to have minimal effect on $\mathrm{pH}$. Bags stored at $40{ }^{\circ} \mathrm{C}$ dried out more quickly, and thus the secondary effect of temperature on moisture content over time affected lime dissolution, with very little effect from temperature directly. EC followed a trend similar to $\mathrm{N}$ release, such that the two variables were highly correlated with the CRF-P substrates across all dates $(r=$ $0.937, P<0.0001, n=120)$. About $25 \%$ of $\mathrm{N}$ from CRF-G treatments was immobilized between 2 and $14 \mathrm{~d}$ of storage. Low moisture content of bags due to low IMC or storage at $40{ }^{\circ} \mathrm{C}$, reduced the rate of $\mathrm{N}$ release from CRF-P treatments. Substrate $\mathrm{P}$ was rapidly immobilized by microbial communities. The percent of $P$ immobilized in the CRF-G treatment was less in substrates with low IMC because of reduced microbial activity in low moisture substrates.
Demand for bagged substrates with CRF amendments is seasonal and in greatest demand during early spring. Because recommendations have been to use substrates amended with CRF within $30 \mathrm{~d}$ (Carlile, 2004; Hulme, 2011; Zaccheo et al., 2013), there is pressure on manufacturers to mix and bag substrates immediately before the sales period. Any strategy that would allow for early mixing and longer storage would ease some of this logistical pressure. Temperatures of 20 and $40{ }^{\circ} \mathrm{C}$ did not seem to differentially affect EC, N, or P. While the experiment was not designed for direct comparison of temperatures with statistical analysis, visual examination of the trends along with 95\% confidence interval bars suggests minimal differences in $\mathrm{EC}, \mathrm{N}$, and $\mathrm{P}$ with respect to the two temperature regimes. It is possible that lower temperatures closer to $0{ }^{\circ} \mathrm{C}$ would have the intended effect of reducing nutrient release, but this approach might not be suitable for the growing media industry due to feasibility and cost of storing large volumes of bagged substrates in controlled environments. Currently, bagged substrates are stored outside (personal communications with numerous commercial sources).

Moisture content had a profound effect on nutrient release. Lower IMC reduced the dissolution of dolomitic lime resulting in lower substrate $\mathrm{pH}$. Lower moisture contents, whether due to IMC or drying through vent holes, resulted in reduced $\mathrm{N}$ release from the CRF-P treatments. Contrary to this, higher moisture contents resulted in greater P immobilization due to greater microbial activity. Considering the dissolution of lime and release of $\mathrm{N}$ and $\mathrm{P}$, the net effect on $\mathrm{EC}$ was primarily a function of $\mathrm{N}$ release. Thus, $\mathrm{EC}$ was also reduced with lower moisture contents. This suggests that manufacturers could use moisture content as a means to slow the release of nutrients in bagged substrates. This would have the added benefit of reduced shipping costs. Currently, substrate manufacturers do not control or modify the moisture content of the bagged substrates; moisture content of the bagged substrate depends solely on the moisture content of the organic matter at the time of mixing and bagging (personal communications with several commercial sources). An additional drawback to substrates with low moisture content is the perception of reduced quality by consumers. Drier substrates may be more dusty, more difficult to handle, and perhaps more difficult to wet (depending on wetting agent).

The objective of this research was to determine how moisture content and storage temperature affected the chemical properties and available nutrients derived from a CRF incorporated into a bagged substrate. Under the conditions of this experiment, temperature seemed to have the primary effect of drying substrates stored at $40{ }^{\circ} \mathrm{C}$ more quickly than those stored at $20^{\circ} \mathrm{C}$. Moisture content had more direct effect on nutrient 
$20^{\circ} \mathrm{C}$
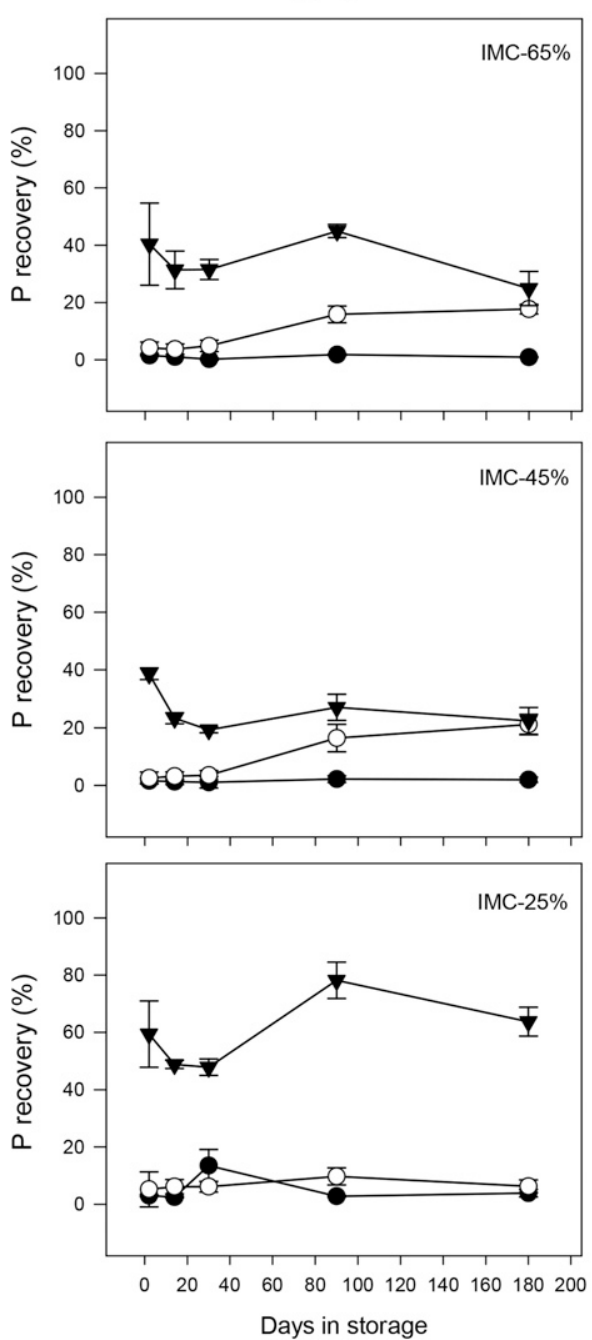

$40^{\circ} \mathrm{C}$
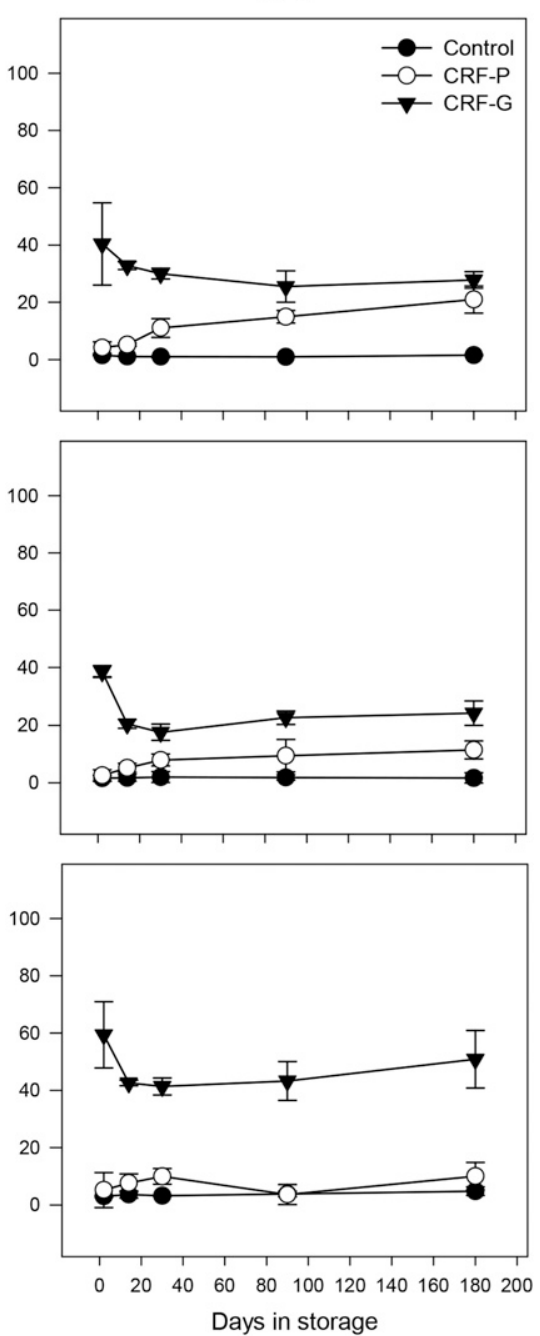

Fig. 5. The recovered water extractable phosphorus $(\mathrm{P})$ from a substrate composed of 60 sphagnum peat: 30 bark : 10 perlite by volume. Data are expressed as mean percent of the total mass of $39.63 \mathrm{mg} P$ applied via the controlled release fertilizer (CRF). Error bars represent the $95 \%$ confidence interval about the mean. Substrates were either not amended with fertilizer (control) or amended with $0.59 \mathrm{~kg} \cdot \mathrm{m}^{-3} \mathrm{~N}$ of a CRF (Osmocote $18 \mathrm{~N}-1.3 \mathrm{P}-5 \mathrm{~K}$ ) that was either ground (CRF-G) or whole prills (CRF-P). Substrates had initial moisture contents of $65 \%$ (higher), $45 \%$ (middle), or $25 \%$ (lower) and were stored at temperatures of either $20^{\circ} \mathrm{C}$ (left) or $40{ }^{\circ} \mathrm{C}$ (right).

release from $\mathrm{CRF}$, as well as lime dissolution and thus $\mathrm{pH}$.

\section{Literature Cited}

Altland, J.E. and K.Y. Jeong. 2016. Dolomitic lime amendment affects pine bark substrate $\mathrm{pH}$, nutrient availability, and plant growth: A review. HortTechnology 26:565-573.

Apodaca, L.E. 2016. Peat: US Geological Survey 2014 minerals yearbook. 13 Oct. 2017. <https:// minerals.usgs.gov/minerals/pubs/commodity/ peat/myb1-2014-peat.pdf>.

Birrenkott, B.A., J. Craig, and G.R. McVey. 2005. A leach collection system to track the release of nitrogen from controlled-release fertilizers in container ornamentals. HortScience 40:18871891.

Brookes, P.C., D.S. Powlson, and D.S. Jenkinson. 1984. Phosphorus in the soil microbial biomass. Soil Biol. Biochem. 16:169-175.
Cabrera, R.I. 1997. Comparative evaluation of nitrogen release patterns from controlledrelease fertilizer by nitrogen leaching analysis. HortScience 32:669-673.

Carlile, W.R. 2004. Changes in organic growing media during storage. Acta Hort. 648:153-159.

Chang-wen, D., J. Zhou, and A. Shaviv. 2006. Release characteristics of nutrients from polymer-coated compound controlled release fertilizers. J. Polymer Environ. 14:223-230.

De Oliveira, S.F., P. Fisher, J. Huang, and S. Mello. 2016. Strategies to provide fertilizer for both production and consumer phases of petunia. HortTechnology 26:164-175.

Dickinson, K. and W.R. Carlile. 1995. The storage properties of wood-based peat-free growing media. Acta Hort. 40:89-96.

Handreck, K.A. 1996. Phosphorus immobilization in wood waste-based potting media. Commun. Soil Sci. Plant Anal. 27:2295-2314.

Huett, D.O. and B.J. Gogel. 2000. Longevities and nitrogen, phosphorus, and potassium release patterns of polymer-coated controlled-release fertilizer at $30^{\circ} \mathrm{C}$ and $40^{\circ} \mathrm{C}$. Commun. Soil Sci. Plant Anal. 31:959-973.

Hulme, F. 2011. The benefits of applying controlled release fertilizers. Greenhouse Mgt. 31(1):6668.

Husby, C.E., A.X. Niemiera, J.R. Harris, and R.D. Wright. 2003. Influence of diurnal temperature on nutrient release patterns of three polymercoated fertilizers. HortScience 38:387-389.

Lindsay, W.L. 1979. Chemical equilibria in soils: Carbonate equilibria. The Blackburn Press, Caldwell, NJ.

Pokorny, F.A. 1979. Pine bark container media An overview. Proc. Intl. Plant Prop. Soc. 29:484-495.

Saadi, I., Y. Laor, S. Medina, A. Krassnovsky, and M. Raviv. 2010. Compost suppressiveness against Fusarium oxysporum was not reduced after one-year storage under various moisture and temperature conditions. Soil Biol. Biochem. 42:626-634.

Scott, M. 1985. Efford gives guidance on bark. Garden Centre Hort. Trade J. Jan.:11-17.

Selmer-Olsen, A.R. and H.R. Gislerod. 1986 Storage of fertilized peat. Acta Hort. 178:163-172.

Shaviv, A., S. Raban, and E. Zaidel. 2003. Modeling controlled nutrient release from polymer coated fertilizer: Diffusion release from single granules. Environ. Sci. Technol. 37:22512256.

Slivka, D.C., T.A. McClure, A.R. Buhr, and R. Albrecht. 1992. Compost: United States supply and demand potential. Biomass Bioenergy 3:281-299.

Todar, K. 2012. Todar's online textbook of bacteriology. 5 May 2017. <http://textbookofbacteriology. net/nutgro.html $>$.

Zaccheo, P., L. Crippa, and C. Cattivello. 2013. Effect of controlled-release fertilizers on chemical parameters of two growing media during 12 months storage. Acta Hort. 1013:327-332. 